\title{
Human Resource Management Practices and Innovation
}

\author{
Laursen, Keld; Foss, Nicolai J.
}

Document Version

Final published version

Publication date:

2012

\section{License \\ CC BY-NC-ND}

Citation for published version (APA):

Laursen, K., \& Foss, N. J. (2012). Human Resource Management Practices and Innovation. Institut for Strategic Management and Globalization. SMG Working Paper No. 5/2012

Link to publication in CBS Research Portal

\section{General rights}

Copyright and moral rights for the publications made accessible in the public portal are retained by the authors and/or other copyright owners and it is a condition of accessing publications that users recognise and abide by the legal requirements associated with these rights.

\section{Take down policy}

If you believe that this document breaches copyright please contact us (research.lib@cbs.dk) providing details, and we will remove access to the work immediately and investigate your claim. 
Human Resource Management Practices and Innovation

Keld Laursen

Nicolai J. Foss

SMG WP 5/2012

September, 2012 
SMG Working Paper No. 5/2012

September, 2012

ISBN: 978-87-91815-80-5

Department of Strategic Management and Globalization Copenhagen Business School

Kilen, Kilevej 14A

2000 Frederiksberg

Denmark

www.cbs.dk/smg 


\title{
HUMAN RESOURCE MANAGEMENT PRACTICES AND INNOVATION
}

\author{
Keld Laursen \\ Department of Organizational Economics and Innovation \\ Copenhagen Business School; Kilevej 14a \\ 2000 Frederiksberg; Denmark \\ kl.ino@cbs.dk \\ and \\ Center for Service Innovation-Department of Strategy and Management \\ Norwegian School of Economics and Business Administration \\ Breiviksveien 40, N-5045 \\ Bergen; Norway \\ Nicolai J. Foss \\ Department of Strategic Management and Globalization \\ Copenhagen Business School; Kilevej 14, $2^{\text {nd }}$ floor \\ 2000 Frederiksberg; Denmark \\ njf.smg@cbs.dk \\ and \\ Center for Service Innovation-Department of Strategy and Management \\ Norwegian School of Economics and Business Administration \\ Breiviksveien 40, N-5045 \\ Bergen; Norway
}

Prepared for the Handbook of Innovation Management, edited by Mark Dodgson, David Gann and Nelson Phillips. Oxford University Press, 2013.

September 19., 2012

Keywords: Human resource management, innovation, organizational complementarities.

JEL Code: B52, M12, M54, 032 


\title{
HUMAN RESOURCE MANAGEMENT PRACTICES AND INNOVATION
}

\begin{abstract}
We survey, organize, and discuss the literature on the role of organizational practices for explaining innovation outcomes. We discuss how individual practices influence innovation, and how the clustering of specific practices matters for innovation outcomes. Relatedly, we discuss various possible mediators of the HRM/innovation link, such as knowledge sharing, social capital and network effects. We argue that the causal mechanisms underlying the HRM/innovation links are still ill-understood, calling for further research.
\end{abstract}




\section{INTRODUCTION}

Human capital is a key, and by all accounts increasingly important, part of the resource-base of firms. Human resources have been called the "key ingredient to organizational success and failure" (Baron and Kreps, 1999), including success and failure in company innovation performance. It is important to understand why and how human capital encourages innovation, and what deployment of human resource management (HRM) practices inside the firm can produce desired levels of innovation performance.

Individual employees, founders, or executives may directly give rise to superior innovation performance (Felin and Hesterly, 2007), as in the cases of "innovative genius" (Glynn, 1996) and "stars" (Lacetera, Cockburn and Henderson, 2004) among. Such human capital is substantially above-normal in innovative capacity, whether this is innate (personified, perhaps, by Bill Gates or Steve Jobs) or acquired through training efforts. University researchers that create entrepreneurial start-ups exemplify the direct link between human capital and innovation performance. Superior innovation performance may also be the result of the "capabilities" stemming from the interactions within a firm's human capital pool (Lepak and Snell, 2002).

The organizational set-up of the firm, notably its human resource management practices, also matter to the contribution of human capital to innovation performance, and it this effect that we mainly address in this chapter. Thus, management deploys training arrangements, makes decisions on reward structures, sets up teams, allocates decision-rights and so on, and these arrangements have implications for the contribution of human capital to innovation.

The influence of these practices may be modelled both in terms of mediator (human capital mediates the influence from HR practices to innovation performance) and moderator (practices 
weaken or reinforce the link from human capital to innovation performance) models. ${ }^{1}$

Extant research suggests multiple mechanisms through which such HRM practices influence the relationships between human capital and innovation. Employee communication networks, as partly shaped by organizational structure, may influence innovation (Tsai, 2001). Motivational research demonstrates that the kind of creative behaviours that underlie successful innovation is stimulated by some kind of rewards but reduced by others (Ryan and Deci, 2000). Managerial styles, the use of feedback, the setting of goals, the use of teams and projects, have all been argued to influence creativity and innovative behaviours.

Organizational practices related to the sourcing, deployment, and upgrading of human capital have been identified in various literatures as influencing innovation performance at the level of firms (Henderson and Cockburn, 1994; Galunic and Rjordan, 1998), networks and industries (Kogut, 2000), and regional or national innovation performance (Almeida and Kogut, 1999; Furman et al., 2002). These practices are important constituent components of "innovation" or "dynamic capabilities" (Teece, 2007). A significant part of such practices are those organizational practices that relate to the attraction, selection, training, assessment, and rewarding of employees. They also include organizational practices that may not conventionally be seen as HRM, such as quality circles, extensive delegation of decision rights, management information systems, and formal and informal communication practices in the firm (see Chapter by Phillips).

In this chapter we survey, organize, and discuss the literature on the \role of organizational practices for explaining innovation outcomes. We discuss how individual practices influence innovation, and how the clustering of specific practices matters for innovation outcomes (cf. Ennen and Richter, 2010). Relatedly, we discuss various possible mediators of the HRM/innovation link,

\footnotetext{
${ }^{1}$ In general, a moderator is a variable that affects the direction and/or strength of the relation between an independent and a dependent variable. A mediator variable is a variable which represents a mechanism through which the focal independent variable is able to (indirectly) influence the dependent variable. See Baron and Kenny (1986) for a detailed exposition.
} 
such as knowledge sharing, social capital and network effects. We argue that the causal mechanisms underlying the HRM/innovation links are still ill-understood, calling for further research.

\section{Organizing the Literature}

The literature on the relation between HRM practices and innovation performances is vast and not easily identifiable, as relevant papers are not necessarily published in HRM journals and may primarily focus on other issues. There is a choice to be made regarding whether research on, say, the impact of monetary incentives on creativity should be included. We specifically put an emphasis on what is often called "new" or "modern" HRM practices (also often called "High-Performance Work Practices") (Laursen and Foss, 2003; Teece, 2007; Colombo and Delmastro, 2008) and its relation to innovation performance. We argue that the literature on HRM practices and innovation can be split into five basic sub-literatures (although inevitably there is some overlap). These are shown diagrammatically in Figure 1. Link I represents a stream of literature that considers the relationship between HRM practices and firm-level financial performance, using innovation as a theoretical link between these variables. Link II denotes a stream of literature that considers the direct link between HRM practices and innovation, while Link III considers a subsequent literature that in addition to this direct link considers mediating and moderating factors of the HRMinnovation relationship. Link VI comprises a small body of literature that has looked not only at the HRM-innovation relationship, but also at antecedents to HRM practices that lead to innovative outcomes. We will discuss these literatures, but first we will identify the most important HRM practices considered in the innovation-related literature.

\section{---Insert Figure 1 here---}

\section{HRM Practices}

The notion of "modern HRM practices" has become an increasingly used way of referring to high levels of delegation of decisions, extensive lateral and vertical communication channels, high 
reward systems, often linked to multiple performance indicators, and other practices that either individually or in various bundles are deployed to achieve high levels of organizational performance (Ichniowski et al., 1997; Zenger and Hesterly, 1997; Colombo and Delmastro, 2002; Teece, 2007; Colombo and Delmastro, 2008). In this context, Guthrie (2001: 181) states that: "The common theme in this literature is an emphasis on utilizing a system of management practices giving employees skills, information, motivation, and latitude and resulting in a workforce that is a source of competitive advantage."

Following Foss, Laursen and Pedersen (2011) we posit that the HRM practices considered in the literature involve: a) delegation of responsibility, such as team production; b) knowledge incentives, such as profit sharing, individual incentives and incentives for knowledge sharing; c) internal communication, encouraged for instance by practices related to knowledge sharing or job rotation; d) employee training, both internal and external; and e) recruitment and retention, such as internal promotion policies). It can be noted that the first three classes of practices include the practices that are typically included as "modern" HRM practices in the literature (Teece, 2007), while the latter two classes in a stylized fashion can be considered more traditional HRM practices. Table 1 provides an overview of our taxonomy and describes the results of a number of representative papers from various parts of the literature.

\section{---Insert Table 1 Here ---}

The early literature was concerned with various "stand-alone" HRM practices and their effect on organizational performance (e.g. Gerhart and Milkovich, 1990; Terpstra and Rozell, 1993). Most of the empirically-based literature since the mid-1990s has focused on the effects of complementary practices, rather than the effect of individual practices (see the recent overview of the general complementarities literature by Ennen and Richter, 2010). The idea of complementarities in our context implies that the introduction of one HRM practice increases the returns to doing more of 
other HRM practices related to innovation output. Note that although the notion of "internal fit" is arguably less precise than the idea of complementarity, this notion is often used in the HRM literature in a similar fashion to that of complementarity (see e.g., Baird and Meshoulam, 1988; Arthur, 1994). Ideas on "systems" or "bundles" of HRM practices (see, Subramony, 2009) operate with a similar logic.

The empirical literature on organizational complementarities suggests two approaches: an interaction and a systems approach (cf. Ennen and Richter, 2010). The interaction approach (e.g., Capelli and Neumark, 2001) examines the effect of a few organizational practices, and in contrast, the systems approach (e.g., Ichniowski et al., 1997; Laursen and Foss, 2003) looks at the relative performance outcomes of entire sets of variables. Given the sheer number of individual practices considered in the literature, the systems approach is dominant, even if it only confers an indirect test of complementarity.

\section{Link I: The Role of Innovation}

Link I represents a large literature stream that has considered innovation mainly in an indirect fashion. This large body of literature (including for instance, Huselid, 1995; Ichniowski et al., 1997; Ichniowski and Shaw, 1999; Datta et al., 2005) considers HRM Practices as explanatory factors (typically complementary) in determining dependent variables such as productivity and profitability. In a typical statement Huselid (1995: 638) notes the

... theoretical literature clearly suggests that the behavior of employees within firms has important implications for organizational performance and that human resource management practices can affect individual employee performance through their influence over employees' skills and motivation through organizational structures that allow employees to improve how their jobs are performed. 
It should be noted, however, that improving "how ... jobs are performed," in this case may refer to incremental process innovations that are not included in the remit of innovation management as described in this book

Research within this literature has typically been published in management journals, but some highly influential studies have been published in economics journals (in particular, Ichniowski et al., 1997). As mentioned above this literature has considered the direct effect of (complementary) HRM practices on economic performance, but also moderated relationships between these variables, for example, by the type of manufacturing strategy pursued by the respondent's firm (Youndt et al., 1996) or its industry affiliation (Datta et al., 2005). The majority of contributions under this heading adopts a cross-sectional approach, and hypothesizes empirical links between a set of complementary HRM practices and economic performance. There is also research based on panel data within this stream. While initial evidence suggested that these organizational practices (Capelli and Neumark, 2001) had little effect on economic performance such as productivity, more recent panel data evidence has tended to confirm the findings from the studies based on crosssectional evidence in that a set of complementary HRM practices have in general been found to have positive influences on economic performance, including productivity and profitability (Van Reenen and Caroli, 2001; Kato and Morishima, 2002; Janod and Saint-Martin, 2004; Colombo et al., 2007). Given this body of literature is only indirectly concerned with innovation management, we will not go in depth with this literature (see, Colombo et al., 2012 for an in-depth review of this literature).

\section{Link II: The Direct Link between HRM and innovation}

Link II refers to literature that has established a direct theoretical and empirical link between HRM practices and innovation outcomes, typically in the form of product or process innovation. 
Until the 2000s, the innovation literature was characterized by relatively scant attention being paid to HRM practices and how they influence innovation performance (Laursen and Foss, 2003). The clear exception is some scholars' interest in Japanese organization and how this connects to innovativeness (Aoki and Dore, 1994). Thus, Freeman (1988, p. 335) explicitly notes how in "Japanese management, engineers and workers grew accustomed to thinking of the entire production process as a system and of thinking in an integrated way about product design and process design," and he makes systematic reference to quality management, horizontal information flows, and other features of modern HRM practices. The concern with horizontal information flows in Project SAPPHO in the late 1960s demonstrates a long-standing awareness of the relation between HRM practices and innovation performance (Rothwell et al., 1974).

Laursen and Foss (2003) supply a number of theoretical arguments for why HRM practices are favourable to innovative activity. One prominent characteristic of many HRM practices is that they increase decentralization by delegating problem-solving rights to the shop-floor. When implemented appropriately, these rights co-exist alongside access to relevant knowledge, much of which may be inherently tacit and thus requires decentralisation for its efficient use. Increased delegation may better allow for the discovery and utilization of local knowledge within the organization, especially when there are rewards in place that support such discovery (Hayek, 1945; Jensen and Meckling, 1992). The increased use of teams is an important component in the set of modern HRM practices. The use of teams also implies that better use can be made of local knowledge, leading to improvements in processes and perhaps also to minor product improvements (Laursen and Foss, 2003: 248). Teams have additional benefits, since they are often composed of different human resource inputs. This may imply that teams bring together knowledge that hitherto existed separately, potentially resulting in process improvements when teams are on the shop floor or "new combinations" that lead to novel products (Schumpeter, 1912/1934), especially when teams 
are in product development departments. Increased knowledge diffusion through job rotation, and increased information dissemination facilitated by IT, may also be expected to provide a positive contribution to innovation performance. Training may be a factor leading to a higher rate of process improvements and may also lead to product innovations.

The adoption of a single such practice may sometimes provide a contribution to innovative performance. The increasingly widespread practice of rewarding shop floor employees for putting forward suggestions for process improvements — such as by giving them a share of the cost savings —is likely to increase incremental innovation activity (Bohnet and Oberholzer-Gee, 2001), regardless of whether or not the firm has employed other organizational practices as well. However, HRM practices should be most conducive to innovation performance when adopted, not singly, but as a system of mutually reinforcing practices. The arguments in favour of this argument are as follows (Laursen and Foss, 2003: 249). The innovation pay-off from giving shop floor employees more problem-solving rights will likely depend on the level of training of such employees. The converse is also likely to hold: employees may invest more in upgrading their skills if they are also given extensive problem-solving rights, especially if they are provided intrinsic or extrinsic motivational encouragements. Rotation and job-related training may have complementary impacts on innovative activity. All these practices are likely to complement various incentive-based remuneration schemes-based on individual, team or firm performance-profit sharing arrangements, and promotion schemes. To the extent that implementing HRM practices is associated with extra effort or with disruption of changing routines, employees will usually demand compensation. From an agency theory perspective one would expect many HRM practices to work well, in both profits and innovation performance, only if accompanied with new, typically more incentive-based, remuneration schemes. 
Arguably the first paper to empirically establish the link between a system of HRM practices and innovative activity was Michie and Sheehan (1999). Using a sample of 480 UK firms drawn from the UK's 1990 Workplace Industrial Relations Survey, the authors investigate the relationships between firms' HRM practices and the level of $R \& D$ expenditure. The results suggest that what the authors term "low road" HRM practices—strict job-description, short term contracts, etc.- - are negatively related to investment in $R \& D$ and the adoption of advanced production equipment. In contrast, "High road" work practices (modern HRM practices) are positively correlated with investment in $\mathrm{R} \& \mathrm{D}$ and modern production equipment.

Laursen and Foss (2003) introduce an innovation-output measure in the HRM literature: the degree of novelty in product innovation. Based on the theoretical arguments presented above regarding complementarities and using data from a Danish survey of 1,900 business firms, the authors conjecture that HRM practices should influence innovation performance positively. Laursen and Foss identify two HRM systems that are conducive to innovation. In the first, seven of a total of nine HRM variables matter nearly equally for the ability to innovate: interdisciplinary workgroups, quality circles, systems for collection of employee proposals, planned job rotation, delegation of responsibility, integration of functions, performance related pay, and pay-for-performance. The second system is dominated by firm-internal and firm-external training. While only two individual practices are strongly significant in explaining the degree of novelty of product innovation the two systems are strongly significant in the regressions. The authors interpret these findings as evidence of complementarity.

In a later study in a sample of 240 UK manufacturing firms also using an innovation output measure of product and process innovation as the dependent variable, Michie and Sheehan (2003), find that firms using HRM practices extensively are much more likely to be process and/or product innovators. The so-called "low road" HRM practices (see above) are found to be negatively 
associated with process innovation, but appear unrelated to product innovation. On the basis of a dataset on approximately 1,400 Swiss firms for the period 1998-2000, Arvanitis (2005) presents findings that are consistent with Michie and Sheehan's findings: a system of HRM practices has a positive effect on firms probability of introducing process innovation, but not of introducing product innovation. Arvanitis also examines whether there is complementarity between numerical flexibility variables (use of part-time work and temporary work) and HRM practices, and complementarity is found between temporary work and HRM practices in process innovation, but not in product innovation. Jimenez-Jimenez and Sanz-Valle's (2008) study of 173 Spanish firms indicate that product, process and administrative innovation contribute positively to business performance and that a comprehensive set of HRM practices enhances innovation. Beugelsdijk (2008) uses a sample of 988 Dutch firms. His results indicate the importance of task autonomy, training and performance-based pay for generating incremental innovations (share of new-to-thefirm products as a percentage of total sales). For radical innovations (share of new-to-the-industry products as a percentage of total sales), the findings underline the importance of task autonomy and flexible working hours. The use of standby (seasonal/temporary/casual/fixed term) contracts is found to be associated with significantly lower levels of innovativeness. Beugelsdijk also detects significant interaction effects between individual HRM practices, proving further evidence in support of the notion of complementarities between these practices.

Love and Roper (2009) using data on UK and German manufacturing plants examine the issue of potential complementarities which may arise when cross-functional teams are used in different elements of the innovation process. Using the "interactions approach" (Ennen and Richter, 2010), they demonstrate that patterns of complementarity are complex; however, they are more marked in the UK than in Germany. The most uniform complementarities are between product design and development and production engineering, with little synergy evident between the more technical 
phases of the innovation process and the development of marketing strategy. The results points to the value of using cross-functional teams for the more technical elements of the innovation process, but also suggests that the development of marketing strategy should remain the domain of specialists.

While all the above studies report findings based on cross-sectional data, other studies have begun to examine longitudinal variation. This is a difficult task, since research on HRM practices inevitably involves questionnaire-based data that will typically suffer from sample attrition as substantial numbers of firms typically disappear over time. On the other hand, the use of data with a time dimension reduces the concerns one might have regarding endogeneity in cross-sectional studies.

Shipton et al. (2005) provide results based on two waves of a survey in which 27 UK manufacturing firms were present in 1993 and 1995. The dependent variable were measured in 1995 and the independent variables in 1993. Even if the study is small scale and only a limited number of control variables are allowed given the small sample, the authors find that HRM practices, excluding monetary incentives, lead to higher levels of product innovation but not to higher levels of process innovation. Monetary incentives linked to appraisal appear to yield a negative impact on product innovation although again it seems that there is no effect on process innovation. These results are only present when the independent variables are lagged: the HRM and incentive variables are insignificant when included in an instantaneous model, indicating that the negative effect is not of a short-term nature.

Zhou et al. (2011) uses a merged dataset based on four waves of Dutch survey data of 2044 firms collected between 1993-2001, with the dependent variables measured at $t$ and independent variables measured at $t-2$. Zhou et al. find that functional flexibility (internal labour mobility), training efforts and highly qualified personnel appear to affect product innovation positively (percentage of sales of 
products new to the market). Zoghi et al. (2010) use a balanced panel of 3,203 establishments from the Canadian Workplace and Employment Survey. The questions about HRM practices were posed in 1999, 2001 and 2003. The dependent variable is a dummy variable representing whether the given establishment introduced product innovation in the given year. The independent variables include decentralization, information-sharing, and incentive pay (and interactions between them). To mitigate the problem related to time-invariant firm heterogeneity and simultaneity bias the authors use a fixed effects model and a model including a lagged dependent variable. The authors find a clear positive link between these factors and product innovation. However, the results suggest that these relationships are not causal (for further discussion of this issue, see below). The results show that the correlation between HRM practices and innovation holds for information-sharing, but is much weaker for decentralized decision-making or incentive pay programs.

\section{Link III: Moderated and Mediated Relationships between HRM and Innovation}

Link III embodies the literature that has established a mediated or moderated theoretical and empirical link between HRM practices and innovation outcomes.

Laursen (2002) posits that organizational theory suggests that more knowledge-intensive production activities often involve higher degrees of strategic uncertainty for firms and performance ambiguity in relation to individual employees. Therefore he expects that HRM practices perform better within knowledge-intensive industries of the economy, as compared to other industries. Using a sample of 726 Danish firms with more than 50 employees the results confirm other findings that HRM practices are more effective in influencing product innovation performance when applied together, as compared with situations in which individual practices are applied alone. Furthermore, he found, the application of complementary HRM practices is more effective for firms in "high" and "medium" knowledge-intensive industries. 
Ritter and Gemünden (2003) examines a model in which "network competence" mediates the relationship between HRM and a composite encompassing process and product innovation. Network competence is defined to be company-specific ability to handle, use, and exploit interorganizational relationships. Drawing upon a sample of 308 German mechanical and electrical engineering companies, results reveal that network competence impacts on a firm's product and process innovation success. The organizational antecedents that impact on a company's network competence include intra-organizational communication and openness of corporate culture.

Lau et al. (2004) outlines the role of organizational culture in the link between the HRM system and the development of new products and services. The authors propose that a developmental culture is a missing link in-between HRM system and innovation outcomes. It is argued that an HRM system that emphasizes extensive training, performance-based reward, and team development is needed to construct an "organizational culture" that is conducive to product innovation. Based on a survey of 332 firms in Hong Kong, the empirical results are consistent with the idea that organizational culture acts as a mediator between firms' HRM systems and product innovation outcomes.

Jensen et al. (2007) contrasts two modes of innovation. The first, the Science, Technology and Innovation (STI) mode, is based on the production and use of codified scientific and technical knowledge. The second, the Doing, Using and Interacting (DUI) mode is akin to a set of HRM practices (except that incentives are not included in the set of HRM practices). Drawing on the results of the 2001 Danish DISKO Survey encompassing 692 firms, analysis shows that firms combining the two modes are more likely to innovate in new products or services than those relying primarily on one mode or the other. In other words, high levels of codified scientific and technical knowledge increases the benefits of HRM practices. 
The study by Beugelsdijk (2008) mentioned above also reports significant interaction effects between HRM practices and firm size, and between HRM practices and R\&D intensity, so that the effect of HRM is complementary to other firm-level variables. Based on data from the German Community Innovation Survey, Rammer et al. (2009) find that R\&D activities are a main driver of innovation output (number of different types of innovations). However, small and medium sized firms without in-house R\&D can yield a similar innovation success when they apply HRM practices to facilitate innovation processes.

Camelo-Ordaz et al. (2008) examine whether the strategic vision of the top management team and the way employees working in teams are rewarded and assessed affect firms' innovation performance. The study is based on a relatively small sample of 97 Spanish companies from hightech industries. The results indicate that innovation output requires the existence of compensation practices based on the ideas generated and developed by project teams aligned with top management teams' strategic vision. Using a sample of 188 UK firms, Oke et al. (2012) find that the interaction of innovation strategy execution by top-management and a set of innovation-focused HRM practices is positively related to product innovation performance.

Lopez-Cabrales et al. (2009) examine how two sets of modern HRM practices (“collaborative HRM practices" and "knowledge-based HRM practices") and employees' knowledge influence the level of innovative activities as they pertain to product innovation. Using a sample of 86 Spanish manufacturing firms, the results indicate that HRM practices are not directly associated with innovation unless they take into account employees' knowledge. Specifically, the analyses suggest a mediating role for firm-specific uniqueness of knowledge between collaborative HRM practices and innovative activity. The findings suggest that the so-called knowledge-based HRM practices and innovation output appear not to be linked. 
Chen and Huang (2009) examine the role of knowledge management capacity (knowledge acquisition, knowledge sharing and knowledge use) in the relationship between HRM practices and innovation performance (measured as both technical and administrative innovation). The authors use regression analysis to test the hypotheses in a sample of 146 Taiwanese firms. The empirical findings indicate that HRM practices are positively related to knowledge management capacity which, in turn, has a positive effect on innovation performance. In other words, the results suggest that knowledge management capacity plays a mediating role between HRM practices and innovation performance.

Foss et al. (2011) argue that firms that attempt to leverage user and customer knowledge in the context of innovation must design an internal organization appropriate to support it and that this can be achieved in particular, through the use of HRM practices, notably those involving intensive vertical and lateral communication, rewarding employees for sharing and acquiring knowledge, and high levels of delegation of decision rights. Using a dataset drawn from a survey of 169 Danish firms among a sample of the largest firms in Denmark, the authors find that the link from customer knowledge to innovation is aided substantially by HRM practices (see also, Petroni et al., 2012, for a discussion of the needed changes in $\mathrm{R} \& \mathrm{D}$ organization and personnel management as a consequence of the implementation of the open innovation model).

An important feature of the model proposed by Foss et al. (2011) pertains to the fact that socalled "knowledge incentives" are part of the organizational variables (positively) mediating the relationship between customer interaction and innovation performance. Somewhat in contrast to this $\mathrm{Fu}$ (2012)—based on a sample of 384 SMEs in the British manufacturing and business services sectors covering the period 1998-2001-finds that while both openness and incentives are positively associated with product innovation efficiency, a substitution effect is found between openness and incentives. Long-term incentives appear to enhance efficiency to a greater extent than 
short-term incentives, and the substitution effect of openness is stronger in the case of long-term incentives. As measures of long-term incentive schemes $\mathrm{Fu}$ uses the proportion of managers and employees participating in a stock option scheme in the total labour force (alternatively, a dummy variable for firms that have introduced a stock option scheme). Short-term incentive schemes are measured using a dummy variable for firms that have introduced performance-related pay. However, Foss et al. (2011) used incentives related to upgrading own skills and to knowledge sharing "knowledge incentives". One explanation for these seemingly conflicting results might thus be that internal knowledge sharing is of central importance when it comes to utilizing external knowledge (cf. Cohen and Levinthal, 1990). For this reason it may be advisable to incentivize this type of behaviour when managers want to benefit from external knowledge. On the other hand, incentive schemes that value individuals' personal innovative performance will increase the innovative effort from these individuals, but might discourage the application of external knowledge.

Moving the focus from firm-level to the individual level, Binyamin and Carmeli (2010) examine a mediation model that suggests that the relationship between structuring of HRM processes and employee creativity is explained by the intervening variables of perceived uncertainty, stress, and the psychological ability to carry out work-tasks (dubbed "psychological availability"). Empirically, the study is based on 213 individuals working in knowledge-intensive firms. The results suggest that structuring of HRM processes is negatively associated with perceived uncertainty and stress. Moreover, these perceptions produce a sense of psychological availability, which in turn enhances employee creativity. Arguably, all other things being equal, increased creativity should lead to more innovation at the firm-level.

All in all, this more recent part of the literature documents that the relationship between HRM practices and innovation outcomes (in particular related to product innovation) is not only a direct 
one. The relationship is often found to be conditional on contingent factors and to be fully or partially mediated by other factors related to knowledge-creation.

\section{Link IV: Antecedents to HRM Practices}

Link IV represents the literature that has established a theoretical and empirical link between HRM practices and their antecedents related to innovation outcomes. The existing literature typically treats HRM variables as being strictly exogenous in explaining innovation outcomes. Accordingly, only a few studies have dealt with this issue. Jackson et al. (1989) examine the driver of the adoption of "personnel practices" that correspond well to HRM practices. Jackson et al. show that these practices are a function of the principal industry sector, the pursuit of innovation as a competitive strategy, the type of manufacturing technology, and of organizational structure.

In a study utilizing data on 1,884 Danish firms examining complementarities between HRM practices, Laursen and Mahnke (2001) confirm that industry-affiliation is a key determinant of the adoption of HRM practices. Moreover, they find that innovator strategy, linkages to suppliers and customers, and linkages to knowledge institutions are important determinants of the adoption of (complementary) HRM practices. Laursen and Mahnke (2001) do not, however, consider innovation outcomes. The paper by Foss et al. (2011) discussed above suggests that an open innovation strategy is an important antecedent to the adoption of a set of complementary HRM practices, and that the combination of interacting with customers and HRM practices is a necessary condition for strong innovation performance. Using a sample of 294 Flemish firms De Winne and Sels (2010) demonstrate that the human capital and the use of a range of external experts are determinants of the adoption of a broad range of HRM practices and that such a broad range of practices in turn are determinants of innovation output (a composite mixture of items relating to administrative, process and product innovation).

\section{RESEARCH GAPS}


The above summary of research involving (modern) HRM practices and innovations reveals considerable activity not only HRM and innovation research, but also strategic management and organizational studies. However, several research gaps exist, calling for additional research efforts. In this section we briefly discuss some of these gaps.

\section{More Time-series Evidence}

As noted above, time series evidence on HRM-practices and innovation outcomes is scarce. Zoghi (2010) found that controls for unobserved heterogeneity significantly weakened their results, and moreover, lagged variables did not provide clear evidence that organizational changes predate innovation. While these findings are extremely interesting and based on sound econometric method, we still need more investigations taking a longitudinal perspective, not least because the fixed effects estimator and the lagged dependent variable estimator tend to produce rather conservative estimates (see also, Zoghi et al., 2010: 632-633).

\section{Clustering of Practices}

In spite of the prominence in HRM/innovation streams of research of thinking on the clustering of practices (cf. Ennen and Richter, 2010), there is still little theorizing that predicts exactly which HRM practices bundle and why, and little empirical work that examines this issue. Empirical work may be somewhat ahead of theory in this area. A good illustration is Laursen and Foss (2003) who find two clusters of HRM practices that are conducive to innovation, but essentially do not theorize why there are differences between them. Empirical work has tended to lump together HRM practices, claiming systems effects. Often empirical research confirms that such systems effects indeed exist, but it may well be that some practices are much more important for the system of practices than others, in other words, that relations of complementarity are stronger between some practices. Clarifying this issue is of obvious practical significance, but extant research has so far had little to say about it. 


\section{Specific Practices}

Laursen and Foss (2003) found that while systems of HRM practices mattered greatly to innovation performance, the contribution of individual practices was negligible. However, some of the practices they considered were measured rather crudely; for example, rewards are represented with a simple variable representing the share of employees involved in any form of pay-for performance (though not piece rates), and their measure for job design only incorporates delegation which is at best an imperfect measure of freedom in the job. Until much more detailed research is conducted, drawing to a much larger extent on the richness of the HRM literature, it is not warranted to conclude that systems of HRM practices matter much more to innovation performance than individual practices.

It should also be noted that single practices may, on conceptual grounds, vary widely with respect to their impact on innovation performance. We have already alluded to potential controversy concerning what kind of incentives are most likely to drive innovation performance. In addition to the temporal dimension of incentives and the tasks that are incentivized, there is also an issue relating to the levels at which incentives are provided. Are group incentives, for example, more effective than individual incentives on innovation performance? To the extent that groups are capable of mobilizing synergistic advantages with respect to creative problem-solving (Paulus, 2000), group-level incentives may make more sense than individual-level incentives.

Moreover, an increasingly prominent argument in motivational psychology asserts that extrinsic motivators, such as monetary incentives, may actually be counterproductive because they tend to drive out the kind of autonomous motivation that is essential for successful problem-solving, learning and creativity (Deci and Ryan, 1985), essential micro-level dimensions of innovative performance. This line of research does not deny that rewards matter, but rather tend to focus on 
softer, less controlling rewards (than contingent performance rewards). The inclusion of such rewards in future research seems highly promising.

\section{Finer Grained and Richer Causal Stories}

While highly attractive because of its emphasis on complementarities between practices, the systems approach that is so influential in research on the HRM/innovation performance link risks obscuring much of the fine-grained causal texture that links HRM practices and innovation. Thus, individual practices may have an impact that is additional to and goes beyond the systems effect.

Consider, for example, job design, one of the most frequently researched practices in the HRM literature. Jobs contain characteristics, such as feedback, the size of the task portfolio, the characteristics of individual task, the ability to carry out a job from the beginning to the end, repetitiveness, and so on, that stimulate different kinds of motivation (Foss et al., 2009). Jobs that imply a greater degree of employee control, autonomy, and non-controlling feedback, for example, are likely to stimulate the autonomous motivation that drives creativity and learning, and, ultimately, innovation performance. Similar arguments may be developed on the basis of other modern HRM practices. Research on teams, for example, has clarified that team problem-solving effectiveness is highly dependent on the clarity to team members of the task structure within the team (Kozlowski and Bell, 2003; Ilgen et al., 2005).

There is considerable room for expanding the understanding of how exactly individual HRM practices contribute to innovation performances by unpacking them and understanding the contextual variables (i.e., moderators) that influence this contribution. A possible outcome of better understanding on this domain is an improved understanding of systems of HRM practices, because one practice may be a relevant contextual variable influencing the effectiveness of another practice.

\section{What Kind of Innovation?}


A final issue concerns the dependent variable in figure 1, that is, performance in terms of product or process innovation. A pertinent question thus is whether there are (modern) HRM practices that are inherently more supportive of one kind of innovation than another. It would seem natural to expect quality circles, for example, to be more conducive to process than to product innovation. Similarly, it could be hypothesized that internal training was also more conducive to process innovation, whereas external training could contribute more to product innovation performance because external training gives employees access to larger networks with more diverse knowledge. Other HRM practices may similarly be hypothesized to have a differential impact on innovation performance.

A further way of advancing research is to dehomogenize the basic process and product innovation categories. Thus, the process innovation category includes not only innovations in the basic production process itself, but also innovations in the administrative structure of the firm (Birkinshaw et al., 2008)—including innovations in HRM. While management innovations may mainly be introduced by the higher echelons of the firm, there are HRM practices, notably reward systems, that may positively influence such innovation. Thus, because management innovations are likely to be implemented across the board in the various departments of a firm, and thus affect the financial performance of the entire company, upper echelons are arguably incentivized to implement such innovations by reward instruments that link pay to overall company performance.

In turn, product innovation may be decomposed into innovations of physical products and innovations of services. Service innovation raises distinct HRM challenges. Thus, while the increasing emphasis on user innovation has pointed to the importance of users and customers in the innovation process in general, the importance of heavy customer and user involvement may be particularly important for service innovations, and it may therefore be particularly to empower employees to cooperate with customers and users in the case of these innovations. 


\section{CONCLUSIONS}

The literature on the links between HRM and innovation that we have surveyed in this chapter has expanded considerably over the last one and a half decades. This may partly reflect that both HRM and innovation have been expanding fields in this period. It arguably also reflects trends in the business world that prompt the emerging integration of HRM and innovation research. As firms increasingly adopt open innovation models and engage with external knowledge sources (see chapter by Dahlander and Alexi), they find that they need to bring new groups of employees into the innovation process. This calls for dedicated training, new performance indicators, new rewards, new ways of communicating with and between employees and so on, in short, it calls for an active HRM effort. Relatedly, firms may open up the innovation process internally, namely by increasingly sourcing ideas and knowledge from organizational members (Dodgson et al., 2006). Such initiatives are also likely to call for new HRM initiatives.

The link between internal organization and innovation performance has been a frequent theme in innovation research since Schumpeter (1942) and Burns and Stalker (1961). Much of the discussion has involved traditional structural variables, typically drawn from structural contingency theory. The emerging research stream in the intersection of HRM and innovation research represents a new, more fine-grained approach to the understanding of the organizational antecedents of innovation performance. However, as we have shown in this chapter, this is a rather recent undertaking and one that represents several research gaps. 


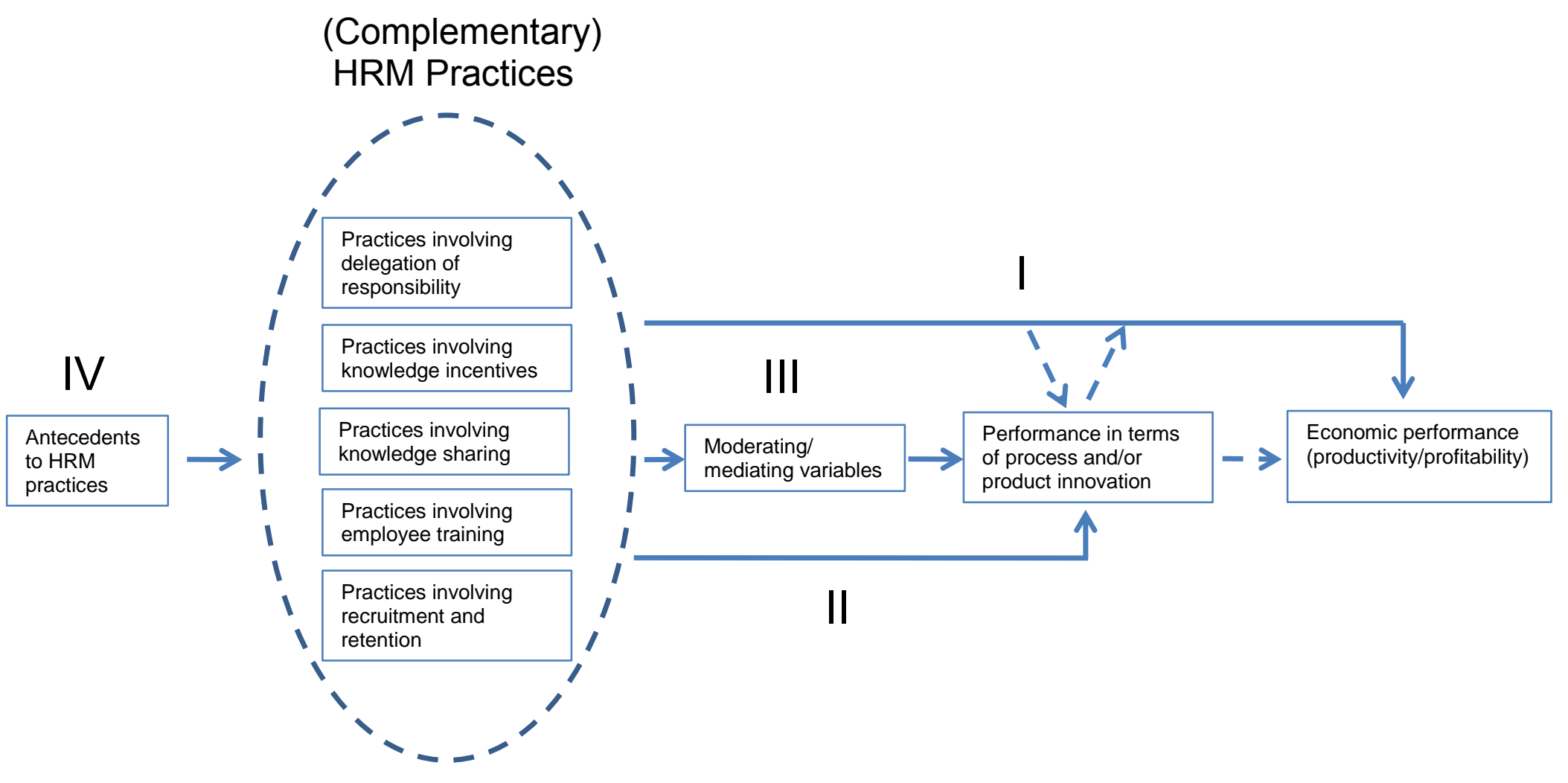

FIGURE 1: THE LINKS BETWEEN HUMAN RESOURCE MANAGEMENT PRACTICES AND INNOVATION 
TABLE 1: Variables in the New HRM Practices Literature

\begin{tabular}{|c|c|c|c|c|c|c|c|c|}
\hline Authors & Unit of analysis & $\begin{array}{l}\text { Dependent } \\
\text { variable }\end{array}$ & Delegation & $\begin{array}{l}\text { Internal } \\
\text { Communication }\end{array}$ & Incentives & Employee training & $\begin{array}{l}\text { Recruitment and } \\
\text { retention }\end{array}$ & Other HMRP variables \\
\hline Huselid (1995) & $\begin{array}{l}968 \text { publicly listed } \\
\text { firms (manufacturing } \\
\text { and private services) }\end{array}$ & $\begin{array}{l}\text { Labor productivity, } \\
\text { Tobin's } q\end{array}$ & $\begin{array}{l}\text { Labor-management } \\
\text { teams, Quality circles }\end{array}$ & $\begin{array}{l}\text { Formal information } \\
\text { sharing program, } \\
\text { Complaint resolution } \\
\text { system }\end{array}$ & $\begin{array}{l}\text { Incentive plans/profit } \\
\text { sharing, formal } \\
\text { appraisals, merit-based } \\
\text { promotion }\end{array}$ & Hours of training & $\begin{array}{l}\text { Formal job analysis, } \\
\text { Internal promotion, } \\
\text { Employment test prior } \\
\text { to recruitment }\end{array}$ & Attitude survey \\
\hline $\begin{array}{l}\text { Ichniowski et al. } \\
\text { (1997) }\end{array}$ & $\begin{array}{l}36 \text { steel finishing } \\
\text { lines within } 17 \text { firms }\end{array}$ & Percent uptime & Teamwork (3 items) & $\begin{array}{l}\text { Communication ( } 2 \\
\text { items), Job rotation }\end{array}$ & Line incentives & $\begin{array}{l}\text { Skills training ( } 2 \\
\text { items) }\end{array}$ & $\begin{array}{l}\text { High screening } \\
\text { recruitment }\end{array}$ & Employment security \\
\hline $\begin{array}{l}\text { Ichniowski and } \\
\text { Shaw (1999) }\end{array}$ & $\begin{array}{l}41 \text { steel finishing } \\
\text { lines within } 19 \text { firms }\end{array}$ & $\begin{array}{l}\text { Percent uptime, } \\
\text { Percent prime yield }\end{array}$ & Teamwork (3 items) & $\begin{array}{l}\text { Labor-management } \\
\text { communication ( } 2 \\
\text { items), Job flexibility ( } 2 \\
\text { items) }\end{array}$ & Incentive pay ( 2 items) & Training ( 2 items) & Recruiting (2 items) & Employment security \\
\hline $\begin{array}{l}\text { Mendelson and } \\
\text { Pillai (1999) }\end{array}$ & $\begin{array}{l}102 \text { business units } \\
\text { from } 81 \text { different } \\
\text { firms (electronics } \\
\text { hardware) }\end{array}$ & $\begin{array}{l}\text { Return on Sales } \\
\text { Return on value } \\
\text { added, Sales growth }\end{array}$ & $\begin{array}{l}\text { Decentralization (3 } \\
\text { items) }\end{array}$ & $\begin{array}{l}\text { Information practices (8 } \\
\text { items) }\end{array}$ & Incentives (3 items) & & & $\begin{array}{l}\text { Focus ( } 3 \text { items), Inter- } \\
\text { organizational network (5 } \\
\text { items) }\end{array}$ \\
\hline $\begin{array}{l}\text { Michie and } \\
\text { Sheehan (1999) }\end{array}$ & $\begin{array}{l}480 \text { firms } \\
\text { (manufacturing and } \\
\text { private services) }\end{array}$ & $\begin{array}{l}\text { R\&D expenditure, } \\
\text { Introduction of } \\
\text { advance } \\
\text { technological } \\
\text { machinery }\end{array}$ & Teamwork & $\begin{array}{l}\text { Flexible job assignment, } \\
\text { Communication ( } 4 \text { items) }\end{array}$ & $\begin{array}{l}\text { Profit sharing, Share } \\
\text { ownership, Individual } \\
\text { pay/Line incentives }\end{array}$ & & & Employment flexibility \\
\hline Mendelson (2000) & $\begin{array}{l}60 \text { business units } \\
\text { (electronics } \\
\text { hardware) }\end{array}$ & $\begin{array}{l}\text { Return on Sales } \\
\text { Return on value } \\
\text { added, Sales growth }\end{array}$ & $\begin{array}{l}\text { Decision architecture (6 } \\
\text { items, including } 3 \\
\text { delegation items) }\end{array}$ & $\begin{array}{l}\text { Knowledge transparency } \\
\text { (6 items) }\end{array}$ & $\begin{array}{l}\text { Decision architecture (6 } \\
\text { items, including } 3 \text { items } \\
\text { measuring incentives) }\end{array}$ & & & $\begin{array}{l}\text { Activity focus (6 items), } \\
\text { (External) Information } \\
\text { awareness ( } 8 \text { items), } \\
\text { Information Age Network } \\
\text { (6 items) }\end{array}$ \\
\hline Guthrie (2001) & $\begin{array}{l}164 \text { firms } \\
\text { (manufacturing and } \\
\text { private services) }\end{array}$ & $\begin{array}{l}\text { Employee retention } \\
\text { rate, Labor } \\
\text { productivity }\end{array}$ & $\begin{array}{l}\text { Teams, Employee } \\
\text { participatory programs }\end{array}$ & Information sharing & $\begin{array}{l}\text { Skill-based pay, Group- } \\
\text { based pay, Performance- } \\
\text { based promotion, } \\
\text { Employee stock } \\
\text { ownership }\end{array}$ & $\begin{array}{l}\text { Training efforts (3 } \\
\text { types) }\end{array}$ & Internal promotion & \\
\hline $\begin{array}{l}\text { Capelli and } \\
\text { Neumark (2001) }\end{array}$ & $\begin{array}{l}\text { Plants in } \\
\text { manufacturing and } \\
\text { private services } \\
\text { (panel, no. of obs. } \\
433 / 666 \text { ) }\end{array}$ & $\begin{array}{l}\text { Labor productivity, } \\
\text { Labor costs, Sales less } \\
\text { labor costs }\end{array}$ & $\begin{array}{l}\text { Self-managed teams, } \\
\text { TQM }\end{array}$ & $\begin{array}{l}\text { Scheduled meetings, Job } \\
\text { rotation }\end{array}$ & $\begin{array}{l}\text { Pay for skills and } \\
\text { knowledge, Profit } \\
\text { sharing }\end{array}$ & & & $\begin{array}{l}\text { Use of computers, Use of } \\
\text { benchmarking vis-à-vis } \\
\text { other organizations }\end{array}$ \\
\hline $\begin{array}{l}\text { Colombo and } \\
\text { Delmastro (2002) }\end{array}$ & $\begin{array}{l}438 \text { manufacturing } \\
\text { plants (panel data) }\end{array}$ & $\begin{array}{l}\text { Change in the } \\
\text { number of } \\
\text { managerial layers }\end{array}$ & $\begin{array}{l}\text { Teamwork, number of } \\
\text { hierarchical layers }\end{array}$ & Job rotation & Individual line incentives & Firm pays for training & & $\begin{array}{l}\text { Type of strategic decision } \\
\text { maker }\end{array}$ \\
\hline
\end{tabular}




\begin{tabular}{|c|c|c|c|c|c|c|c|c|}
\hline $\begin{array}{l}\text { Laursen and Foss } \\
\text { (2003) }\end{array}$ & $\begin{array}{l}1900 \text { firms } \\
\text { (manufacturing and } \\
\text { private services) }\end{array}$ & Product innovation & $\begin{array}{l}\text { Delegation of respon- } \\
\text { sibility, Interdisciplinary } \\
\text { work groups, Quality } \\
\text { circles }\end{array}$ & $\begin{array}{l}\text { Integration of functions, } \\
\text { Job rotation, Systems for } \\
\text { collection of employee } \\
\text { proposals }\end{array}$ & Pay-for-performance & $\begin{array}{l}\text { Firm-internal and } \\
\text { firm-external training }\end{array}$ & & \\
\hline $\begin{array}{l}\text { Hamilton et al. } \\
\text { (2003) }\end{array}$ & $\begin{array}{l}\text { Workers within a } \\
\text { single firm (panel } \\
\text { data) }\end{array}$ & Productivity & $\begin{array}{l}\text { Team vs. no-team } \\
\text { production }\end{array}$ & & $\begin{array}{l}\text { Team vs. individual } \\
\text { piece rates }\end{array}$ & & & \\
\hline Datta et al. (2005) & $\begin{array}{l}132 \text { manufacturing } \\
\text { firms }\end{array}$ & Labor productivity & Self-directed teams & $\begin{array}{l}\text { Programs designed to } \\
\text { elicit participation and } \\
\text { employee input, } \\
\text { Complaint resolution } \\
\text { system, Provide } \\
\text { information to mana- } \\
\text { gement }\end{array}$ & $\begin{array}{l}\text { Compensation based on } \\
\text { group performance, Pay } \\
\text { is based on a skill or } \\
\text { knowledge-based } \\
\text { system, Formal } \\
\text { performance feedback }\end{array}$ & $\begin{array}{l}\text { Intensive/ extensive } \\
\text { training }\end{array}$ & $\begin{array}{l}\text { Tests administered prior } \\
\text { to hiring, Internal } \\
\text { promotions, } \\
\text { Intensive/extensive } \\
\text { recruiting }\end{array}$ & \\
\hline $\begin{array}{l}\text { Collins and Smith } \\
(2006)\end{array}$ & $\begin{array}{l}513 \text { high-technology } \\
\text { companies }\end{array}$ & $\begin{array}{l}\text { Revenue from new } \\
\text { products, Sales } \\
\text { growth }\end{array}$ & & $\begin{array}{l}\text { Knowledge Exchange } \\
\text { and Combination ( } 8 \\
\text { items) }\end{array}$ & $\begin{array}{l}\text { Incentive Policies (3 } \\
\text { items) }\end{array}$ & & $\begin{array}{l}\text { Selection Policies (4 } \\
\text { items) }\end{array}$ & \\
\hline $\begin{array}{l}\text { Colombo et al. } \\
\text { (2007) }\end{array}$ & $\begin{array}{l}109 \text { single plant firms } \\
\text { (panel data) }\end{array}$ & Profitability & $\begin{array}{l}\text { Decentralization, } \\
\text { Number of plant's } \\
\text { hierarchical levels, TQM }\end{array}$ & $\begin{array}{l}\text { Formal team practices, } \\
\text { Job rotation }\end{array}$ & $\begin{array}{l}\text { Profit sharing, Individual } \\
\text { incentives }\end{array}$ & & & \\
\hline Beugelsdijk (2008) & $\begin{array}{l}988 \text { firms } \\
\text { (manufacturing and } \\
\text { private services) }\end{array}$ & $\begin{array}{l}\text { Incremental, Radical } \\
\text { innovation }\end{array}$ & & $\begin{array}{l}\text { Job autonomy, Task } \\
\text { rotation }\end{array}$ & Performance-based pay & $\begin{array}{l}\text { Training policies, } \\
\text { Internal training, } \\
\text { External training, } \\
\text { Procedures for } \\
\text { education of } \\
\text { employees }\end{array}$ & $\begin{array}{l}\text { Procedures for } \\
\text { recruitment }\end{array}$ & $\begin{array}{l}\text { Procedures for quality } \\
\text { maintenance }\end{array}$ \\
\hline $\begin{array}{l}\text { Chen and Huang } \\
\text { (2009) }\end{array}$ & $\begin{array}{l}146 \text { firms } \\
\text { (manufacturing and } \\
\text { private services) }\end{array}$ & $\begin{array}{l}\text { Administrative } \\
\text { innovation ( } 4 \text { items), } \\
\text { Technical innovation } \\
\text { (3 items) }\end{array}$ & Participation (3 items) & & $\begin{array}{l}\text { Appraisal ( } 3 \text { items), } \\
\text { compensation ( } 3 \text { items) }\end{array}$ & Training (6 items) & Staffing (3 items) & \\
\hline $\begin{array}{l}\text { Lopez-Cabrales et } \\
\text { al. (2009) }\end{array}$ & $\begin{array}{l}86 \text { firms } \\
\text { (manufacturing) }\end{array}$ & $\begin{array}{l}\text { Innovative Activity, } \\
\text { Profits }\end{array}$ & Delegation (two items) & $\begin{array}{l}\text { Cross-functional teams, } \\
\text { job-rotation }\end{array}$ & $\begin{array}{l}\text { Performance appraisal ( } 4 \\
\text { items) compensation ( } 3 \\
\text { items) }\end{array}$ & $\begin{array}{l}\text { Training activities } \\
\text { (two items) }\end{array}$ & $\begin{array}{l}\text { Selection process ( } 4 \\
\text { items), promotion from } \\
\text { within }\end{array}$ & $\begin{array}{l}\text { Job-security, socialization } \\
\text { program, Tutoring }\end{array}$ \\
\hline Zoghi et al. (2010) & $\begin{array}{l}3203 \text { firms (panel } \\
\text { data) (manufacturing } \\
\text { and private services) }\end{array}$ & Product innovation & Decentralization & Info-sharing & $\begin{array}{l}\text { Individual incentive pay, } \\
\text { Group Incentive pay, } \\
\text { Profit sharing plan }\end{array}$ & & & \\
\hline Foss et al. (2011) & $\begin{array}{l}132 \text { firms } \\
\text { (manufacturing and } \\
\text { private services) }\end{array}$ & $\begin{array}{l}\text { Innovation } \\
\text { performance ( } 2 \\
\text { items) }\end{array}$ & $\begin{array}{l}\text { Delegation of } \\
\text { Responsibility (two } \\
\text { items) }\end{array}$ & $\begin{array}{l}\text { Internal communication } \\
\text { ( } 2 \text { items) }\end{array}$ & $\begin{array}{l}\text { Knowledge } \\
\text { Incentives (two items) }\end{array}$ & & & \\
\hline
\end{tabular}

Note: Adapted and extended from Foss, Laursen and Pedersen (2011). 


\section{REFERENCES}

Almeida, P., and Kogut, B. 1999. Localization of knowledge and the mobility of engineers in regional networks. Management Science, 45(7): 905-917.

Arthur, J. B. 1994. Effects of Human ressource Systems on Manufacturing Performance and Turnover. Academy of Management Journal, 37(3): 670-687.

Arvanitis, S. 2005. Modes of labor flexibility at firm level: are there any implications for performance and innovation? Evidence for the Swiss economy. Industrial and Corporate Change, 14(6): 993-1016.

Baird, L., and Meshoulam, I. 1988. Managing Two Fits of Strategic Human Resource Management. The Academy of Management Review, 13(1): 116-128.

Baron, J. N., and Kreps, D. M. 1999. Strategic Human Resources: Frameworks for General Managers. New York: John Wiley.

Baron, R. M., and Kenny, D. A. 1986. The moderator-mediator variable distinction in social psychological research: conceptual, strategic, and statistical considerations. Journal of Personality and Social Psychology, 51(6): 1173-1182.

Beugelsdijk, S. 2008. Strategic human resource practices and product innovation. Organization Studies, 29(6): 821-847.

Binyamin, G., and Carmeli, A. 2010. Does structuring of human resource management processes enhance employee creativity? The mediating role of psychological availability. Human Resource Management, 49(6): 999-1024.

Birkinshaw, J., Hamel, G., and Mol, M. 2008. Management Innovation. The Academy of Management Review ARCHIVE, 33(4): 825-845.

Bohnet, I., and Oberholzer-Gee, F. 2001. Pay for Performance: Motivation and Selection Effects. Cambridge, Massachusetts: Harvard Business School.

Burns, T., and Stalker, G. M. 1961. The Management of Innovation. London: Tavistock.

Camelo-Ordaz, C., De la Luz Fernandez-Alles, M., and Valle-Cabrera, R. 2008. Top management team's vision and human resources management practices in innovative Spanish companies. International Journal of Human Resource Management, 19(4): 620-638.

Capelli, P., and Neumark, D. 2001. Do "high-performance" work practices improve establishmentlevel outcomes? Industrial and Labor Relations Review, 54(4): 737-775.

Chen, C., and Huang, J. 2009. Strategic human resource practices and innovation performance - The mediating role of knowledge management capacity. Journal of Business Research, 62(1): 104-114.

Cohen, W. M., and Levinthal, D. A. 1990. Absorptive Capacity: A New Perspective of Learning and Innovation. Administrative Science Quarterly, 35(1): 128-152.

Collins, C. J., and Smith, K. G. 2006. Knowledge exchange and combination: the role of Human resource practices in the performance of High-technology firms. Academy of Management Journal, 49(3): 544-560.

Colombo, M. G., and Delmastro, M. 2002. The determinants of organizational change and structural inertia: Technological and organizational factors. Journal of Economics \& Management Strategy, 11(4): 595-635.

Colombo, M. G., and Delmastro, M. 2008. The Economics of Organizational Design: Theoretical Insights and Empirical Evidence. Hampshire, England: Palgrave Macmillan.

Colombo, M. G., Delmastro, M., and Rabbiosi, L. 2007. "High performance" work practices, decentralization, and profitability: evidence from panel data. Industrial and Corporate Change, 16(6): 1037-1067. 
Colombo, M. G., Delmastro, M., and Rabbiosi, L. 2012. Organizational design and firm performance. In R. T. Christopher, and W. F. Shughart II (Eds.), Oxford Handbook in Managerial Economics. Oxford Oxford University Press.

Datta, D. K., Guthrie, J. P., and Wright, P. M. 2005. Human resource management and labor productivity: Does industry matter? Academy of Management Journal, 48(1): 135-145.

De Winne, S., and Sels, L. 2010. Interrelationships between human capital, HRM and innovation in Belgian start-ups aiming at an innovation strategy. International Journal of Human Resource Management, 21(11): 1863-1883.

Deci, E. L., and Ryan, R. M. 1985. Intrinsic motivation and self-determination in human behavior. New York: Plenum Press.

Dodgson, M., Gann, D., and Salter, A. 2006. The role of technology in the shift towards open innovation: the case of Procter \& Gamble. R\&D Management, 36(3): 333-346.

Ennen, E., and Richter, A. 2010. The Whole Is More Than the Sum of Its Parts: Or Is It? A Review of the Empirical Literature on Complementarities in Organization. Journal of Management, 36(1): 207-233.

Felin, T., and Hesterly, W. 2007. The knowledge-based view, nested heterogeneity, and new value creation: philosophical considerations on the locus of knowledge. Academy of Management Review, 32(1): 195-218.

Foss, N. J., Laursen, K., and Pedersen, T. 2011. Linking Customer Interaction and Innovation: The Mediating Role of New Organizational Practices. Organization Science, 22(4): 980-999.

Foss, N. J., Minbaeva, D., Reinholt, M., and Pedersen, T. 2009. Stimulating Knowledge Sharing Among Employees: The Contribution of Job Design. Human Resource Management, 48: 871-893.

Freeman, C. 1988. Japan: a New National System of Innovation? In G. Dosi, C. Freeman, R. Nelson, G. Silverberg, and L. L. G. Soete (Eds.), Technical Change and Economic Theory. London: Pinter Publishers.

$\mathrm{Fu}, \mathrm{X} .2012$. How does openness affect the importance of incentives for innovation? . Research Policy, 41(3): 512-523.

Furman, J. L., Porter, M. E., and Stern, S. 2002. The determinants of national innovative capacity. Research Policy, 31(6): 899-933.

Galunic, D. C., and Rjordan, S. 1998. Resource re-combinations in the firm: Knowledge structures and the potential for Schumpeterian innovation. Strategic Management Journal, 19: 11931201.

Gerhart, B., and Milkovich, G. T. 1990. Organizational differences in managerial compensation and firm performance. Academy of Management Journal, 33(4): 663-691.

Glynn, M. A. 1996. Innovative Genius: A Framework for Relating Individual and Organizational Intelligences to Innovation. The Academy of Management Review, 21(4): 1081-1111.

Guthrie, J. P. 2001. High-Involvement Work Practices, Turnover, and Productivity: Evidence from New Zealand. Academy of Management Journal, 44(1): 180-190.

Hamilton, B. H., Nickerson, J. A., and Owan, H. 2003. Team incentives and worker heterogeneity: An empirical analysis of the impact of teams on productivity and participation. Journal of Political Economy, 111(3): 465-497.

Hayek, F. A. 1945. The Use of Knowledge in Society. American Economic Review, 35(September): 519-530.

Henderson, R., and Cockburn, I. 1994. Measuring Competence: Exploring Firm Effects in Pharmaceutical Research. Strategic Management Journal, 15(Winter Special Issue): 63-84. 
Huselid, M. A. 1995. The Impact of Human Resource Management Practices on Turnover, Productivity, and Corporate Financial Performance. Academy of Management Journal, 38(3): 635-672.

Ichniowski, C., and Shaw, K. 1999. The effects of human resource management systems on economic performance: An international comparison of US and Japanese plants. Management Science, 45(5): 704-721.

Ichniowski, C., Shaw, K., and Prennushi, G. 1997. The Effects of Human Resource Management Practices on Productivity: A Study of Steel Finishing Lines. American Economic Review, 87(3): 291-313.

Ilgen, D. R., Hollenbeck, J. R., Johnson, M., and Jundt, D. 2005. Teams in organizations: From input-process-output models to IMOI models. Annual Review of Psychology, 56(1).

Jackson, S. E., Schuler, R. S., and Rivero, J. C. 1989. Organizational Characteristics as Predictors of Personnel Practices. Personnel Psychology, 42: 727-786.

Janod, V., and Saint-Martin, A. 2004. Measuring the Impact of Work Reorganization on Firm Performance: Evidence from French Manufacturing, 1995-1999. Labour Economics, 11(6): 785-798.

Jensen, M., Johnson, B., Lorenz, E., and Lundvall, B. 2007. Forms of knowledge and modes of innovation. Research Policy, 36(5): 680-693.

Jensen, M. C., and Meckling, W. H. 1992. Specific and general knowledge and organizational structure. In L. Werin, and H. Wijkander (Eds.), Contract Economics: 251-274. Oxford: Blackwell.

Kato, T., and Morishima, M. 2002. The Productivity Effects of Participatory Employment Practices: Evidence from New Japanese Panel Data. Industrial Relations 41, 41(4): 487-520.

Kogut, B. 2000. The network as knowledge: generative rules and the emergence of structure. Strategic Management Journal, 21(3): 405-425.

Kozlowski, S. W. J., and Bell, B. S. 2003. Work Groups and Teams in Organizations, Handbook of Psychology: John Wiley \& Sons, Inc.

Lau, C., and Ngo, H. 2004. The HR system, organizational culture, and product innovation. International Business Review, 13(6): 685-703.

Laursen, K. 2002. The importance of sectoral differences in the application of complementary HRM practices for innovation performance. International Journal of the Economics of Business, 9(1): 139-156.

Laursen, K., and Foss, N. 2003. New human resource management practices, complementarities and the impact on innovation performance. Cambridge Journal of Economics, 27(2): 243263.

Laursen, K., and Mahnke, V. 2001. Knowledge Strategies, Firm Types, and Complementarity in Human-resource Practices. Journal of Management and Governance, 5(1): 1-27.

Lepak, D. P., and Snell, S. A. 2002. Examining the human resource architecture: The relationships among human capital, employment, and human resource configurations. Journal of Management, 28(4): 517-543.

Lopez-Cabrales, A., Perez-Luno, A., and Valle Cabrera, R. 2009. Knowledge as a mediator between HRM practices and innovative activity. Human Resource Management, 48(4): 485-503.

Love, J., and Roper, S. 2009. Organizing innovation: complementarities between cross-functional teams. Technovation, 29(3): 192-203.

Mendelson, H. 2000. Organizational architecture and success in the information technology industry. Management Science, 46(4): 513-529.

Mendelson, H., and Pillai, R. R. 1999. Information age organizations, dynamics, and performance. Journal of Economic Behavior and Organization, 38(3): 253-281. 
Michie, J., and Sheehan, M. 1999. HRM Practices, R\&D Expenditure and Innovative Investment: Evidence from the UK's 1990 Workplace Industrial Relations Survey. Industrial and Corporate Change, 8(2): 211-234.

Michie, J., and Sheehan, M. 2003. Labour market deregulation, "flexibility" and innovation. Cambridge Journal of Economics, 27(1): 123-143.

Oke, A., Walumbwa, F. O., and Myers, A. 2012. Innovation Strategy, Human Resource Policy, and Firms' Revenue Growth: The Roles of Environmental Uncertainty and Innovation Performance. Decision Sciences, 43(2): 273-302.

Paulus, P. 2000. Groups, Teams, and Creativity: The Creative Potential of Idea-generating Groups. Applied Psychology, 49(2): 237-262.

Petroni, G., Venturini, K., and Verbano, C. 2012. Open innovation and new issues in R\&D organization and personnel management. The International Journal of Human Resource Management, 23(1): 147-173.

Rammer, C., Czarnitzki, D., and Spielkamp, A. 2009. Innovation success of non-R\&D-performers: substituting technology by management in SMEs. Small Business Economics, 33(1): 35-58.

Ritter, T., and Gemunden, H. 2003. Network competence: its impact on innovation success and its antecedents. Journal of Business Research, 56(9): 745-755.

Rothwell, R., Freeman, C., Jervis, P., Robertson, A., and Townsend, J. 1974. SAPPHO Updated Project SAPPHO Phase 2. Research Policy, 3(3): 258-291.

Ryan, R. M., and Deci, E. L. 2000. Intrinsic and Extrinsic Motivations: Classic Definitions and New Directions. Contemporary Educational Psychology, 25(1): 54-67.

Schumpeter, J. A. 1912/1934. The Theory of Economic Development: An Inquiry into Profits, Capital, Credit, Interest and the Business Cycle (R. Opie, Trans.). London: Oxford University Press.

Schumpeter, J. A. 1942. Capitalism, Socialism and Democracy (paperback edition ed.). London: Routledge.

Shipton, H., Fay, D., West, M., Patterson, M., and Birdi, K. 2005. Managing people to promote innovation. Creativity and Innovation Management, 14(2): 118-128.

Subramony, M. 2009. A meta-analytic investigation of the relationship between HRM bundles and firm performance. Human Resource Management, 48(5): 745-768.

Teece, D. J. 2007. Explicating dynamic capabilities: the nature and microfoundations of (sustainable) enterprise performance. Strategic Management Journal, 28(13): 1319-1350.

Terpstra, D. E., and Rozell, E. J. 1993. The relationship of staffing practices to organizational level measures of performance. Personnel Psychology, 46(1): 27-48.

Tsai, W. P. 2001. Knowledge transfer in intra-organizational networks: Effects of network position and absorptive capacity on business unit innovation and performance. Academy of Management Journal, 44(5): 996-1004.

Van Reenen, J., and Caroli, E. 2001. Skill-Biased Organizational Change? Evidence from a Panel of British and French Establishments. Quarterly Journal of Economics, 116(4): 1449-1492.

Youndt, M. A., Snell, S. A., Dean, J. W., Jr., and Lepak, D. P. 1996. Human Resource Management, Manufacturing Strategy, and Firm Performance. The Academy of Management Journal, 39(4): 836-866.

Zenger, T., and Hesterly, W. S. 1997. The Disaggregation of Corporations: Selective Intervention, High-Powered Incentives and Molecular Units. Organization Science, 8(3): 209-222.

Zhou, H., Dekker, R., and Kleinknecht, A. 2011. Flexible labor and innovation performance: evidence from longitudinal firm-level data. Industrial and Corporate Change, 20(3): 941968. 
Zoghi, C., Mohr, R., and Meyer, P. 2010. Workplace organization and innovation. Canadian Journal of Economics-Revue Canadienne De Economique, 43(2): 622-639. 


\section{SMG - Working Papers \\ www.cbs.dk/smg \\ 2003}

2003-1: Nicolai J. Foss, Kenneth Husted, Snejina Michailova, and Torben Pedersen: Governing Knowledge Processes: Theoretical Foundations and Research Opportunities.

2003-2: Yves Doz, Nicolai J. Foss, Stefanie Lenway, Marjorie Lyles, Silvia Massini, Thomas P. Murtha and Torben Pedersen: Future Frontiers in International Management Research: Innovation, Knowledge Creation, and Change in Multinational Companies.

2003-3: Snejina Michailova and Kate Hutchings: The Impact of In-Groups and OutGroups on Knowledge Sharing in Russia and China CKG Working Paper.

2003-4: Nicolai J. Foss and Torben Pedersen: The MNC as a Knowledge Structure: The Roles of Knowledge Sources and Organizational Instruments in MNC Knowledge Management CKG Working Paper.

2003-5: Kirsten Foss, Nicolai J. Foss and Xosé H. Vázquez-Vicente: “Tying the Manager's Hands": How Firms Can Make Credible Commitments That Make Opportunistic Managerial Intervention Less Likely CKG Working Paper.

2003-6: Marjorie Lyles, Torben Pedersen and Bent Petersen: Knowledge Gaps: The Case of Knowledge about Foreign Entry.

2003-7: Kirsten Foss and Nicolai J. Foss: The Limits to Designed Orders: Authority under “Distributed Knowledge" CKG Working Paper.

2003-8: Jens Gammelgaard and Torben Pedersen: Internal versus External Knowledge Sourcing of Subsidiaries - An Organizational Trade-Off.

2003-9: Kate Hutchings and Snejina Michailova: Facilitating Knowledge Sharing in Russian and Chinese Subsidiaries: The Importance of Groups and Personal Networks Accepted for publication in Journal of Knowledge Management.

2003-10: Volker Mahnke, Torben Pedersen and Markus Verzin: The Impact of Knowledge Management on MNC Subsidiary Performance: the Role of Absorptive Capacity CKG Working Paper.

2003-11: Tomas Hellström and Kenneth Husted: Mapping Knowledge and Intellectual Capital in Academic Environments: A Focus Group Study Accepted for publication in Journal of Intellectual Capital CKG Working Paper.

2003-12: Nicolai J Foss: Cognition and Motivation in the Theory of the Firm: Interaction or "Never the Twain Shall Meet"? Accepted for publication in Journal des Economistes et des Etudes Humaines CKG Working Paper.

2003-13: Dana Minbaeva and Snejina Michailova: Knowledge Transfer and Expatriation Practices in MNCs: The Role of Disseminative Capacity.

2003-14: Christian Vintergaard and Kenneth Husted: Enhancing Selective Capacity Through Venture Bases. 


\section{4}

2004-1: Nicolai J. Foss: Knowledge and Organization in the Theory of the Multinational Corporation: Some Foundational Issues

2004-2: Dana B. Minbaeva: HRM Practices and MNC Knowledge Transfer

2004-3: Bo Bernhard Nielsen and Snejina Michailova: Toward a Phase-Model of Global Knowledge Management Systems in Multinational Corporations

2004-4: Kirsten Foss \& Nicolai J Foss: The Next Step in the Evolution of the RBV: Integration with Transaction Cost Economics

2004-5: Teppo Felin \& Nicolai J. Foss: Methodological Individualism and the Organizational Capabilities Approach

2004-6: Jens Gammelgaard, Kenneth Husted, Snejina Michailova: Knowledge-sharing Behavior and Post-acquisition Integration Failure

2004-7: Jens Gammelgaard: Multinational Exploration of Acquired R\&D Activities

2004-8: Christoph Dörrenbächer \& Jens Gammelgaard: Subsidiary Upgrading? Strategic Inertia in the Development of German-owned Subsidiaries in Hungary

2004-9: Kirsten Foss \& Nicolai J. Foss: Resources and Transaction Costs: How the Economics of Property Rights Furthers the Resource-based View

2004-10: Jens Gammelgaard \& Thomas Ritter: The Knowledge Retrieval Matrix: Codification and Personification as Separate Strategies

2004-11: Nicolai J. Foss \& Peter G. Klein: Entrepreneurship and the Economic Theory of the Firm: Any Gains from Trade?

2004-12: Akshey Gupta \& Snejina Michailova: Knowledge Sharing in Knowledge-Intensive Firms: Opportunities and Limitations of Knowledge Codification

2004-13: Snejina Michailova \& Kate Hutchings: Knowledge Sharing and National Culture: A Comparison Between China and Russia

\section{5}

2005-1: Keld Laursen \& Ammon Salter: My Precious - The Role of Appropriability Strategies in Shaping Innovative Performance

2005-2: Nicolai J. Foss \& Peter G. Klein: The Theory of the Firm and Its Critics: A Stocktaking and Assessment

2005-3: Lars Bo Jeppesen \& Lars Frederiksen: Why Firm-Established User Communities Work for Innovation: The Personal Attributes of Innovative Users in the Case of Computer-Controlled Music

2005-4: Dana B. Minbaeva: Negative Impact of HRM Complementarity on Knowledge Transfer in MNCs

2005-5: Kirsten Foss, Nicolai J. Foss, Peter G. Klein \& Sandra K. Klein: Austrian Capital 
Theory and the Link Between Entrepreneurship and the Theory of the Firm

2005-1: Nicolai J. Foss: The Knowledge Governance Approach

2005-2: Torben J. Andersen: Capital Structure, Environmental Dynamism, Innovation Strategy, and Strategic Risk Management

2005-3: Torben J. Andersen: A Strategic Risk Management Framework for Multinational Enterprise

2005-4: Peter Holdt Christensen: Facilitating Knowledge Sharing: A Conceptual Framework

2005-5 Kirsten Foss \& Nicolai J. Foss: Hands Off! How Organizational Design Can Make Delegation Credible

2005-6 Marjorie A. Lyles, Torben Pedersen \& Bent Petersen: Closing the Knowledge Gap in Foreign Markets - A Learning Perspective

2005-7 Christian Geisler Asmussen, Torben Pedersen \& Bent Petersen: How do we Capture "Global Specialization" when Measuring Firms' Degree of internationalization?

2005-8 Kirsten Foss \& Nicolai J. Foss: Simon on Problem-Solving: Implications for New Organizational Forms

2005-9 Birgitte Grøgaard, Carmine Gioia \& Gabriel R.G. Benito: An Empirical Investigation of the Role of Industry Factors in the Internationalization Patterns of Firms

2005-10 Torben J. Andersen: The Performance and Risk Management Implications of Multinationality: An Industry Perspective

2005-11 Nicolai J. Foss: The Scientific Progress in Strategic Management: The case of the Resource-based view

2005-12 Koen H. Heimeriks: Alliance Capability as a Mediator Between Experience and Alliance Performance: An Empirical Investigation Into the Alliance Capability Development Process

2005-13 Koen H. Heimeriks, Geert Duysters \& Wim Vanhaverbeke: Developing Alliance Capabilities: An Empirical Study

2005-14 JC Spender: Management, Rational or Creative? A Knowledge-Based Discussion

\section{6}

2006-1: Nicolai J. Foss \& Peter G. Klein: The Emergence of the Modern Theory of the Firm

2006-2: Teppo Felin \& Nicolai J. Foss: Individuals and Organizations: Thoughts on a Micro-Foundations Project for Strategic Management and Organizational Analysis

2006-3: Volker Mahnke, Torben Pedersen \& Markus Venzin: Does Knowledge Sharing 
Pay? An MNC Subsidiary Perspective on Knowledge Outflows

2006-4: Torben Pedersen: Determining Factors of Subsidiary Development

2006-5 Ibuki Ishikawa: The Source of Competitive Advantage and Entrepreneurial Judgment in the RBV: Insights from the Austrian School Perspective

2006-6 Nicolai J. Foss \& Ibuki Ishikawa: Towards a Dynamic Resource-Based View: Insights from Austrian Capital and Entrepreneurship Theory

2006-7 Kirsten Foss \& Nicolai J. Foss: Entrepreneurship, Transaction Costs, and Resource Attributes

2006-8 Kirsten Foss, Nicolai J. Foss \& Peter G. Klein: Original and Derived Judgement: An Entrepreneurial Theory of Economic Organization

2006-9 Mia Reinholt: No More Polarization, Please! Towards a More Nuanced Perspective on Motivation in Organizations

2006-10 Angelika Lindstrand, Sara Melen \& Emilia Rovira: Turning social capital into business? A study of Swedish biotech firms' international expansion

2006-11 Christian Geisler Asmussen, Torben Pedersen \& Charles Dhanaraj: Evolution of Subsidiary Competences: Extending the Diamond Network Model

2006-12 John Holt, William R. Purcell, Sidney J. Gray \& Torben Pedersen: Decision Factors Influencing MNEs Regional Headquarters Location Selection Strategies

2006-13 Peter Maskell, Torben Pedersen, Bent Petersen \& Jens Dick-Nielsen: Learning Paths to Offshore Outsourcing - From Cost Reduction to Knowledge Seeking

2006-14 Christian Geisler Asmussen: Local, Regional or Global? Quantifying MNC Geographic Scope

2006-15 Christian Bjørnskov \& Nicolai J. Foss: Economic Freedom and Entrepreneurial Activity: Some Cross-Country Evidence

2006-16 Nicolai J. Foss \& Giampaolo Garzarelli: Institutions as Knowledge Capital: Ludwig M. Lachmann's Interpretative Institutionalism

2006-17 Koen H. Heimriks \& Jeffrey J. Reuer: How to Build Alliance Capabilities

2006-18 Nicolai J. Foss, Peter G. Klein, Yasemin Y. Kor \& Joseph T. Mahoney: Entrepreneurship, Subjectivism, and the Resource - Based View: Towards a New Synthesis

2006-19 Steven Globerman \& Bo B. Nielsen: Equity Versus Non-Equity International Strategic Alliances: The Role of Host Country Governance

\section{7}

2007-1 Peter Abell, Teppo Felin \& Nicolai J. Foss: Building Micro-Foundations for the Routines, Capabilities, and Performance Links 
2007-2 Michael W. Hansen, Torben Pedersen \& Bent Petersen: MNC Strategies and Linkage Effects in Developing Countries

2007-3 Niron Hashai, Christian G. Asmussen, Gabriel R.G. Benito \& Bent Petersen: Predicting the Diversity of Foreign Entry Modes

2007-4 Peter D. Ørberg Jensen \& Torben Pedersen: Whether and What to Offshore?

2007-5 Ram Mudambi \& Torben Pedersen: Agency Theory and Resource Dependency Theory: Complementary Explanations for Subsidiary Power in Multinational Corporations

2007-6 Nicolai J. Foss: Strategic Belief Management

2007-7 Nicolai J. Foss: Theory of Science Perspectives on Strategic Management Research: Debates and a Novel View

2007-8 Dana B. Minbaeva: HRM Practices and Knowledge Transfer in MNCs

2007-9 Nicolai J. Foss: Knowledge Governance in a Dynamic Global Context: The Center for Strategic Management and Globalization at the Copenhagen Business School

2007-10 Paola Gritti \& Nicolai J. Foss: Customer Satisfaction and Competencies: An Econometric Study of an Italian Bank

2007-11 Nicolai J. Foss \& Peter G. Klein: Organizational Governance

2007-12 Torben Juul Andersen \& Bo Bernhard Nielsen: The Effective Ambidextrous Organization: A Model of Integrative Strategy Making Processes.

\section{8}

2008-1 Kirsten Foss \& Nicolai J. Foss: Managerial Authority When Knowledge is Distributed: A Knowledge Governance Perspective

2008-2 Nicolai J. Foss: Human Capital and Transaction Cost Economics.

2008-3 Nicolai J. Foss \& Peter G. Klein: Entrepreneurship and Heterogeneous Capital.

2008-4 Nicolai J. Foss \& Peter G. Klein: The Need for an Entrepreneurial Theory of the Firm.

2008-5 Nicolai J. Foss \& Peter G. Klein: Entrepreneurship: From Opportunity Discovery to Judgment.

2008-6 Mie Harder: How do Rewards and Management Styles Influence the Motivation to Share Knowledge?

2008-7 Bent Petersen, Lawrence S. Welch \& Gabriel R.G. Benito: Managing the Internalisation Process - A Theoretical Perspective.

2008-8 Torben Juul Andersen: Multinational Performance and Risk Management Effects: Capital Structure Contingencies. 
2008-9 Bo Bernard Nielsen: Strategic Fit and the Role of Contractual and Procedural Governance in Alliances: A Dynamic Perspective.

2008-10 Line Gry Knudsen \& Bo Bernhard Nielsen: Collaborative Capability in R\&D Alliances: Exploring the Link between Organizational and Individual level Factors.

2008-11 Torben Juul Andersen \& Mahesh P. Joshi: Strategic Orientations of Internationalizing Firms: A Comparative Analysis of Firms Operating in Technology Intensive and Common Goods Industries.

2008-12 Dana Minbaeva: HRM Practices Affecting Extrinsic and Intrinsic Motivation of Knowledge Receivers and their Effect on Intra-MNC Knowledge Transfer.

2008-13 Steen E. Navrbjerg \& Dana Minbaeva: HRM and IR in Multinational Corporations: Uneasy Bedfellows?

2008-14 Kirsten Foss \& Nicolai J. Foss: Hayekian Knowledge Problems in Organizational Theory.

2008-15 Torben Juul Andersen: Multinational Performance Relationships and Industry Context.

2008-16 Larissa Rabbiosi: The Impact of Subsidiary Autonomy on MNE Knowledge Transfer: Resolving the Debate.

2008-17 Line Gry Knudsen \& Bo Bernhard Nielsen: Organizational and Individual Level Antecedents of Procedural Governance in Knowledge Sharing Alliances.

2008-18 Kirsten Foss \& Nicolai J. Foss: Understanding Opportunity Discovery and Sustainable Advantage: The Role of Transaction Costs and Property Rights.

2008-19 Teppo Felin \& Nicolai J. Foss: Social Reality, The Boundaries of Self-fulfilling Prophecy, and Economics.

2008-20 Yves Dos, Nicolai J. Foss \& José Santos: A Knowledge System Approach to the Multinational Company: Conceptual Grounding and Implications for Research

2008-21 Sabina Nielsen \& Bo Bernhard Nielsen: Why do Firms Employ foreigners on Their Top Management Teams? A Multi-Level Exploration of Individual and Firm Level Antecedents

2008-22 Nicolai J. Foss: Review of Anders Christian Hansen's “Uden for hovedstrømmen - Alternative strømninger i økonomisk teori"

2008-23 Nicolai J. Foss: Knowledge, Economic Organization, and Property Rights

2008-24 Sjoerd Beugelsdijk, Torben Pedersen \& Bent Petersen: Is There a Trend Towards Global Value Chain Specialization? - An Examination of Cross Border Sales of US Foreign Affiliates 
2008-25 Vikas Kumar, Torben Pedersen \& Alessandro Zattoni: The performance of business group firms during institutional transition: A longtitudinal study of Indian firms

2008-26 Sabina Nielsen \& Bo B. Nielsen: The effects of TMT and Board Nationality Diversity and Compensation on Firm Performance

2008-27 Bo B. Nielsen \& Sabina Nielsen: International Diversification Strategy and Firm Performance: A Multi-Level Analysis of Firm and Home Country Effects

\section{9}

2009-1 Nicolai J. Foss: Alternative Research Strategies in the Knowledge Movement: From Macro Bias to Micro-Foundations and Multi-Level Explanation

2009-2 Nicolai J. Foss \& Peter G. Klein: Entrepreneurial Alertness and Opportunity Discovery: Origins, Attributes, Critique

2009-3 Nicolai J. Foss \& Dana B. Minbaeva: Governing Knowledge: The Strategic Human Resource Management Dimension

2009-4 Nils Stieglitz \& Nicolai J. Foss: Opportunities and New Business Models: Transaction Cost and Property Rights Perspectives on Entrepreneurships

2009-5 Torben Pedersen: Vestas Wind Systems A/S: Exploiting Global R\&D Synergies

2009-6 Rajshree Agarwal, Jay B. Barney, Nicolai J. Foss \& Peter G. Klein: Heterogeneous Resources and the Financial Crisis: Implications of Strategic Management Theory

2009-7 Jasper J. Hotho: A Measure of Comparative Institutional Distance

2009-8 Bo B. Nielsen \& Sabina Nielsen: The Impact of Top Management Team Nationality Diversity and International Experience on Foreign Entry Mode

2009-9 Teppo Felin \& Nicolai Juul Foss: Experience and Repetition as Antecedents of Organizational Routines and Capabilities: A Critique of Behaviorist and Empiricist Approaches

2009-10 Henk W. Volberda, Nicolai J. Foss \& Marjorie E. Lyles: Absorbing the Concept of Absorptive Capacity: How To Realize Its Potential in the Organization Field

2009-11 Jan Stentoft Arlbjørn, Brian Vejrum Wæhrens, John Johansen \& Torben Pedersen: Produktion i Danmark eller offshoring/outsourcing: Ledelsesmæssige udfordringer 


\section{0}

2010-1 Dana B. Minbaeva, Kristiina Mäkelä \& Larissa Rabbiosi: Explaining Intraorganizational Knowledge Transfer at the Individual Level

2010-2 Dana B.Minbaeva \& Torben Pedersen: Governing Individual Knowledge Sharing Behavior

2010-3 Nicolai J. Foss \& Peter G. Klein: Alertness, Judgment, and the Antecedents of Entrepreneurship

2010-4 Nicolai J.Foss \& Joseph T.Mahoney: Exploring Knowledge Governance

2010-5 Jasper J. Hotho, Florian Becker-Ritterspach \& Ayse Saka-Helmhout: Enriching Absorptive Capacity Through Social Interaction

2010-6 Nicolai J. Foss \& Bo B. Nielsen: Researching Collaborative Advantage: Some Conceptual and Multi-level Issues

2010-7 Nicolai J. Foss \& Nils Stieglitz: Modern Resource-Based Theory(ies)

2010-8 Christian Bjørnskov \& Nicolai J. Foss: Do Economic Freedom and Entrepreneurship Impact Total Factor Productivity?

2010-9 Gabriel R.G. Benito, Bent Petersen \& Lawrence S. Welch: Mode Combinations and International Operations: Theoretical Issues and an Empirical Investigation

\section{1}

2011-1 Peter D. Ørberg Jensen \& Bent Petersen: Human Asset Internalization and Global Sourcing of Services - A Strategic Management Analysis on Activity-level

2011-2 Mie Harder: Management Innovation Capabilities: A Typology and Propositions for Management Innovation Research

2011-3 Mie Harder: Internal Antecedents of Management Innovation: The effect of diagnostic capability and implementation capability 
2011-4 Mie Harder: Explaining Management Innovation Pervasiveness: The Role of Internal Antecedents

2011-5 Mie Harder: Internal Determinants of Product Innovation and Management Innovation: The Effect of Diagnostic Capability and Implementation Capability

2011-6 Nicolai J. Foss, Peter G. Klein \& Per L. Bylund: Entrepreneurship and the Economics of the Firm

2011-7 Nicolai J. Foss \& Jacob Lyngsie: The Emerging Strategic Entrepreneurship Field: Origins, Key Tenets and Research Gaps

2011-8 Nicolai J. Foss: Entrepreneurship in the Context of the Resource-based View of the Firm

2011-9 Bent Petersen, Gabriel R.G. Benito, Olesya Dovgan \& Lawrence Welch: Offshore outsourcing: A dynamic, operation mode perspective

2011-10 Bent Petersen, Gabriel R. G. Benito \& Lawrence Welch: Dynamics of Foreign Operation Modes and their Combinations: Insights for International Strategic Management

2011-11 Nicolai J. Foss: Teams, Team Motivation, and the Theory of the Firm

2011-12 Nicolai J. Foss: Knowledge Governance: Meaning, Nature, Origins, and Implications

2011-13 Nicolai J. Foss, Kirsten Foss \& Phillip C. Nell: MNC Organizational Form and Subsidiary Motivation Problems: Controlling Intervention Hazards in the Network MNC

2011-14 Kåre Moberg: Evaluating Content Dimensions in Entrepreneurship Education

\section{2}

2012-1 Nicolai J. Foss, Nicholas Argyres, Teppo Felin \& Todd Zenger: The Organizational Economics of Organizational Capability and Heterogeneity: A Research Agenda 
2012-2 Torben J. Andersen, Carina Antonia Hallin \& Sigbjørn Tveterås: A Prediction Contest: The Sensing of Frontline Employees Against Executive Expectations

2012-3 Peter G. Klein, Jay B. Barney \& Nicolai J. Foss: Strategic Entrepreneurship

2012-4 Kåre Moberg: The Impact of Entrepreneurship Education and Project-based Education on Students' Personal Development and Entrepreneurial Intentions at the Lower Levels of the Educational System: Too Much of Two Good Things?

2012-5 Keld Laursen \& Nicolai J. Foss: Human Resource Management Practices and Innovation 